\title{
Review of Chitra Banerjee's Arranged Marriage Stories
}

\author{
Niranjana G. \\ Bhuvaneswari
}

\section{Book Review:}

Chitra Banerjee Divakaruni, ‘Arranged Marriage Stories', Anchor, 1996, 320p, ISBN13: 978-0385483506

Reviewed by Niranjana G, Research Scholar, VIT Chennai, Bhuvaneswari, Assistant Professor, VIT Chennai

Arranged Marriage Stories (1996) acts as the mirror to Indian American women's way of life during the last decades of the twentieth century and it is an exploration of the raising feminist consciousness among the immigrant women entangled in the web of dual identities. It was written when the American way of life was a dream for Indian men and women. The author based the natives out of Calcutta with ample metaphors such as ' $G h u$ Ghu' bird, betel leaves for substantiating Calcutta experience. In all the short stories, the author juxtaposed arranged marriage with love marriage, wherein she foregrounded women's condition concerning marriage. The consciousness of Indian women struggling between dual identities is the point of retrospection left for the reader. The bookcomprises 11 short stories and they all reflect women's immigrant experience except for the story 'Bats'. All the female protagonists perform the prescribed role of their gender at some point in their life and confirm the cultural code set by society as Butler puts it. The cultural setting is predominantly upper-middle-class Indian families except for the story "The Bats."

In the short story 'The Bats', the bats act as a metaphor for the mother. There are times and still at some places, women fear creating identities outside the domestic sphere of life, and they identify themselves not only sub-ordinate to the masculinity hubris but also constantly playing the oppressed. The mother in this short story goes back to the 
abusive husband again fearing the mockery of society. She validates herself through her husband. The mother whose name unknown till the end of the story remains as a foil for all the other protagonists. As Fredrich Engels says, 'A Proletariat is much better than a woman' because they have a past to look up to, but the past was also the same for Indian women. They do not have any pre-gendered phase to go back to.

In the short story, 'clothes', the author foregrounds clothes as a metaphor of identity for a woman who hailed from a village and got married to an American Indian. The clothes act as the identity in the realm of gender. The developing personality of Mita is traced over her choice of clothes. Simon de Beauvoir points out that women need freedom more than happiness which implicitly underlines the stagnant attitude of females once their basic needs are met, and they are happy. This statement holds for many Indian women even today many are brought up to believe that domestic needs and duties are more important than individual needs. Nonetheless, the condition of Indian housewife changes depending on the society where she lives in. Mita's realization for economic independence and her awareness of her condition began once her husband was dead. She realized that she did not want to spend the rest of her life as an invalid under the veil and the very color of the widow's attire kindled her consciousness and provoked her to seek economic independence which will liberate her from the cultural constraints of her community.

In the short story, 'Silver Payments, Golden Roofs. the author juxtaposes the experiences of immigrant married and unmarried (young) women who want to pursue higher education in America. Silver Payments and Golden Roofs are metaphors of dreamland. Aunt Pratima's mind is doodled in her native place and its richness, but Jayanti wanted to be one among the Americans. The embodiment of Aunt Pratima is reflected in the clingy atmosphere of the house whereas Jayanti's dreams are the embodiment of her true inner self. The author brings back our senses alive through the use of taste metaphors in experiencing the foreign land.

In the short story, 'Love', the second person narrator assumes the inner voice of the protagonist. Here the Protagonist is entangled in the web of relationships and through her relationship; she is confronted with her conscience. The uniqueness of the narrative stands in the memory act of reflection the autobiographical pact of the short story. By the memory act of recollecting, the narrator brings back the harsh memories of her past and relived her sufferings. The choice of metaphors blends well with the mood of the characters and the surroundings. The clear sub-ordinate position of Indian women and her performativity of the feminine role to an American partner is foregrounded in the novella.

'The Maid Servant's Story' is one of the stories that delineate the subversion of three women belonging to the same generation and the author employed the technique of embedded narrative where Deepa Mashi acts as the link between the narratives. The author touched upon the dimension of pregnancy through the novella, 'The Ultrasound', and here again, the Indianness and hybridity towards the idea of pregnancy and marriage are examined through the two female characters. 
In the short story, 'Affair', the house, and the kitchen are the embodiments of Abha whereas beauty and work are the embodiment of Meena. In the other stories, the author juxtaposes Abha and Meena and raised Abha's consciousness through Meena's decision for her life. 'I will have made up to him partly for my failure to hold on to his father' (Divakaruni 277). This is the evidence suggesting the performativity of the feminine role in the short story; 'Meeting Mrinal' is that Asha overcomes the taunting of Indianness by avoiding cooking Indian food.

The very existence of Indian women is entangled in the web of marriage and child-rearing and their inability to betray their Indian conscience. The right to decide their own life was the new offering in the free land. Women raise themselves to defy the society-imposed role through economic independence in the foreign land. The author skillfully used clothes, food, spices, and kitchen as metaphors for Indian experience and identity. Even though, the book dates to the end of the twentieth century, the immigrant experience and feelings in the foreign land remain the same except for the employment and the promises it offers to us today.

Identity is embodied in food, taste, and clothes for the women protagonists in the short stories. Bengali cultural memory is manifested in their food and clothes. Food and clothes act as the sites of the cultural memory and a symbol of Bengali culture which symbolizes belongingness to the culture. Our cultural memories are embodied in the form of material things and gain agency through performativity. This justifies that a cultural memory needs to be performed to gain representation and get actualized in the mind of the individual. These short stories can also be interpreted as a symbol of Bengali culture or the sites of memory for the Bengali culture in India. Also, this text provides insight into how metaphors can perform the act of mediation and remediation of cultural memory.

\section{Works Cited}

Chang, Jung. Wild Swans: Three Daughters of China. London: HarperCollins, 1993.

Chun, Shinae. Talking Points: Korean American Coalition National Convention.

Centennial of Korean Immigration to the United States, January 11, 2003

http://apa.si.edu/Curriculum\%20Guide-Final/unit1.htm

Kristeva, Julia. Revolution in Poetic Language [1974]. Trans. Margaret Waller. New York: Columbia University Press, 1984.

Lacan, Jacques. The Four Fundamental Concepts of Psycho-analysis. Tranns. Alan

Sheridan. London: Hogarth Press, 1977.

Marshall, Brenda, K. Teaching the Postmodern: Fiction and Theory. New York, London: Routledge, 1992.

Millard, Kenneth. Contemporary American Fiction: An Introduction To American

Fiction Since 1970. Usa: Oxford University Press, 2000

Murfin, Ross; and Supryia, M. Ray. "The Bedford Glossary of Critical and Literary

Terms."Boston, New York: Bedford/St. Martin's, 2003.

Robbins, Ruth. Transitions: Subjectivity. China: Palgrave Macmillan, 2005.

Zahavi, Dan. Subjectivity and Selfhood: Investigating the First-Person Perspective.

Massachusetts, London, England: MIT Press Cambridge, 2006. 


\section{The Author}

\section{Niranjana}

Email: niranjjan87@gmail.com

\section{Bhuvaneswari G}

\section{The Article}

Date Sent: 25/01/2021

Date Revised: 27/03/2021

Date Accepted: 27/03/2021 